\title{
The Interplay of Different Types of Governance in Horizontal Cooperations
}

\section{A View on Logistics Service Providers}

Raue, Jan Simon; Wieland, Andreas

\author{
Document Version \\ Accepted author manuscript \\ Published in: \\ International Journal of Logistics Management
}

DOI:

10.1108/IJLM-08-2012-0083

Publication date:

2015

License

Unspecified

Citation for published version (APA):

Raue, J. S., \& Wieland, A. (2015). The Interplay of Different Types of Governance in Horizontal Cooperations: A View on Logistics Service Providers. International Journal of Logistics Management, 26(2), 401-423.

https://doi.org/10.1108/IJLM-08-2012-0083

Link to publication in CBS Research Portal

\section{General rights}

Copyright and moral rights for the publications made accessible in the public portal are retained by the authors and/or other copyright owners and it is a condition of accessing publications that users recognise and abide by the legal requirements associated with these rights.

\section{Take down policy}

If you believe that this document breaches copyright please contact us (research.lib@cbs.dk) providing details, and we will remove access to the work immediately and investigate your claim. 


\title{
The interplay of different types of governance in horizontal cooperations: A view on logistics service providers
}

\author{
Jan Simon Raue and Andreas Wieland \\ Journal article (Post print version)
}

Citation: Jan Simon Raue, Andreas Wieland, (2015) "The interplay of different types of governance in horizontal cooperations: A view on logistics service providers ", The International Journal of Logistics Management, Vol. 26 Iss: 2, pp.401 - 423

DOI: http://dx.doi.org/10.1108/IJLM-08-2012-0083

Uploaded to Research@CBS: September 2015

Available at: http://research.cbs.dk/da/publications/the-interplay-of-different-types-of-governancein-horizontal-cooperations\%284de0953a-3920-409a-b63a-60342c976528\%29.html

(C) 2015 Emerald 


\title{
The interplay of different types of governance in horizon- tal cooperations: A view on logistics service providers
}

\author{
Jan Simon Raue \\ The Kühne Foundation Center for International Logistics Networks, \\ Technische Universität Berlin, Berlin, Germany, and \\ Andreas Wieland \\ Department of Operations Management, Copenhagen Business School, Frederiksberg, Denmark
}

]

To cite this document: Jan Simon Raue, Andreas Wieland (2015), The interplay of different types of governance in horizontal cooperations. The International Journal of Logistics Management, Vol. 26, No. 2. pp. 401-423. http://dx.doi.org/10.1108/IJLM-08-2012-0083

\begin{abstract}
Purpose - Over the last decades, horizontal cooperations between logistics service providers (LSPs) have become a well-established organizational form and their use is expected to grow even further in the future. In spite of this increasing importance of horizontal LSP cooperations, little research has been done to reveal how to govern these relationships successfully. Particularly, the role of contractual governance and its interplay with operational governance mechanisms remain to be investigated.

Design/methodology/approach - This research analyzes the influence of contractual governance on the effectiveness of two types of operational governance (a formal and a relational type). It relates contractual governance and operational governance to two major outcome dimensions of horizontal cooperations between LSPs (cooperation-based firm performance and cooperation-based learning) and uses multivariate statistical methods.

Findings - The results reveal that contractual safeguarding is able to partly replace process formalization when aiming for better cooperation-based firm performance and complement process formalization when aiming for cooperation-based learning. At the same time, relational capital is always complemented by contractual safeguarding independently from the desired cooperation outcome.

Originality/value - This is the first study analyzing the role of contractual safeguarding in horizontal cooperations between logistics service providers. It shows its interplay with operational governance mechanisms, and, thereby, not only considers a relational type of operational governance, but also a formal type.
\end{abstract}

Keywords: Horizontal cooperation, contractual safeguarding, governance, logistics service providers, empirical study, transaction cost economics

\section{Introduction}

For quite some time, horizontal cooperations have grown in importance for logistics service providers (LSPs) and today more than half of LSPs are engaged in one or multiple such cooperations with other LSPs (Muir, 2010; Schmoltzi and Wallenburg, 2011). Through cooperations with potential competitors, LSPs are able to benefit in two fields: First, LSPs can access tangible resources which are directly exploitable (e.g., extended common transportation networks, warehouse infrastructure or more complex service packages by combining partners' resources) and directly contribute to 
the LSPs' firm performance (Cruijssen et al., 2007a; Cruijssen et al., 2007b; Selviaridis and Spring, 2007; Verstrepen et al., 2009; Klaas-Wissing and Albers, 2010). Second, LSPs can access intangible resources, which are not directly exploitable (e.g., know-how and information) and provide the basis for future innovations, and, thus, enhance future firm performance (Carbone and Stone, 2005; Steinicke et al., 2012).

To achieve these benefits, adequate management of the cooperation is necessary. Here, a major challenge lies in cooperating while at the same time being competitors, a setting of "co-opetition" which fundamentally differs from vertical cooperations (Bengtsson and Kock, 2000; Tsai, 2002). This important field of cooperation management has, however, been long neglected by logistics research, which mainly addresses cooperations between LSPs and their customers (Panayides and So, 2005; Fugate et al., 2009; Yazdanparast et al., 2010) and other vertical cooperations along the supply chain (Ryals and Humphries, 2010; Braziotis and Tannock, 2011).

Within the management of co-opetitive relationships, the right set of governance mechanisms is a major success factor (Hoetker and Mellewigt, 2009; Schmoltzi and Wallenburg, 2012; Steinicke et al., 2012). To achieve an effective governance structure, companies can utilize a wide range of possible governance mechanisms in cooperations. Among them, (a) two types of operational governance, a relational type (Kale et al., 2000; Hammervoll, 2011; Lado et al., 2011) and a formal type (e.g., process formalization) (Murray and Kotabe, 2005), and (b) contractual governance (Poppo and Zenger, 2002; Teng and Das, 2008) are governance forms of major importance.

Prior research has shown that both operational and contractual governance mechanisms reach higher effectiveness in interplay with other governance mechanisms (Kale and Singh, 2009). At the same time, how to design their interplay remains unclear, and, two main schools have emerged among cooperation management scholars (Kale and Singh, 2009). The first school of thought suggests that contractual governance reduces the need for operational governance and vice versa, i.e., they each substitute or crowd out the other (Bradach and Eccles, 1989; Gulati, 1995; Wang et al., 2011), whereas the second school finds that contractual governance strengthens the positive effects of operational governance, i.e., they are complementary in enhancing alliance outcome (Poppo and Zenger, 2002; Aalbers, 2010).

However, a research gap exists regarding which of the schools to follow when setting up governance for horizontal LSP cooperations. Additionally, prior research does not differentiate between distinctive types of operational governance. It only views at the interplay of contractual governance and one relational type of operational governance - typically just called "relational governance" -, although a formal type of operational governance can be a very effective alternative, in particular in LSP cooperations (Steinicke et al., 2012), which should be taken in consideration when establishing governance in cooperations. Consequently, also the interplay of contractual governance and the formal type of operational governance is of major interest, when establishing an effective set of governance mechanisms, but has so far not been researched. A further research gap remains about how firms can maximize their benefits from cooperations through better combining governance mechanisms, which is reflected in Reuer and Ariño's (2007) call for further research considering the outcome effects of governance in cooperations.

This study addresses these research gaps by outlining and evaluating the interplay of contractual and operational governance in horizontal LSP cooperations regarding their outcome effects. Based on a sample of 209 LSPs engaged in horizontal cooperations, this study employs a quantitative hypotheses testing empirical approach 
using structural equation modeling. Thus, it provides empirical insights into what combinations of governance mechanisms are most effective in terms of cooperation outcome. The following section gives an overview of the focal constructs of this research.

\section{Focal constructs}

\section{Governing LSP cooperations}

Governance helps to fulfill two of the most important tasks of cooperation management, (1) the coordination of cooperation activities and resources and (2) the mitigation of the risk of opportunistic behavior between cooperation partners (Reuer and Ariño, 2007; Hoetker and Mellewigt, 2009; Steinicke et al., 2012).

To achieve this, cooperating firms can employ various forms of governance in cooperations. Two especially important ones are:

\section{Operational governance}

In this research, operational governance is defined as the governance which accounts for the day-to-day governance of activities and processes. Operational governance consists of two types: a formal and a relational type of operational governance (Hoetker and Mellewigt, 2009; Schmoltzi and Wallenburg, 2012; Steinicke et al., 2012). First, the formal type of operational governance refers to rules, policies and procedures, which form a mutually agreed upon framework of how operational processes within the cooperation activities are supposed to take place, and are independent from personal relationships (Murray and Kotabe, 2005). In this research, we focus on process formalization as a mechanism of the formal type of operational governance. Process formalization is defined as spelling out detailed tasks, activities, schedules and operating procedures to govern the cooperation (c.f., Murray and Kotabe, 2005). An example are standard operating procedures defining how cooperation partners have to handle certain cargo types. Process formalization provides an agreed upon formal basis for day-to-day interactions between cooperating firms on the operational level. Furthermore, it clarifies goals and responsibilities, and provides transparency about cooperation processes (Das and Teng, 1998; Min et al., 2005). Process formalization is particularly effective in LSP cooperations (Schmoltzi and Wallenburg, 2012), which rely on high degrees of standardization regarding time schedules and quality rules and mostly need clearly defined organizational routines and control systems to function soundly (Klaas-Wissing and Albers, 2010).

Second, the relational type of operational governance refers to operational governance mechanisms that are interpersonal and social in nature and mainly enhance the building of trust and social identification (Dyer and Singh, 1998; Jap and Ganesan, 2000). They correspond to the social exchange perspective according to which cooperative exchanges are embedded within a system of social interactions (Granovetter, 1985). In this research, we focus on relational capital as a mechanism of the relational type of operational governance. Relational capital involves an atmosphere of forbearance, respect and balanced reciprocity (Wallenburg and Raue, 2011). In addition, it creates a mutual confidence that no party will exploit the others' vulnerabilities even if there is such opportunity (Kale et al., 2000). An example for strong relational capital are cooperation partners trusting each other even when other partners deal with own customers. Relational capital is an effective governance mechanism of inter-organizational relationships of LSPs (Wallenburg and Raue, 2011), in which relational aspects have often been proven to be crucial success factors (Hofenk et al., 2011). 


\section{Contractual governance}

Contractual governance is setting the legal parameters of the cooperation agreement (Heide, 1994; Kale et al., 2000; Poppo and Zenger, 2002; Li et al, 2010; Nielsen, 2010). It amounts to the use of contractual safeguards on which the cooperating firms jointly agree. Thus, in investigating contractual governance, we focus on contractual safeguarding. It enables cooperation partners to set forth their mutual rights and obligations through the specification of inputs to and expected outputs from the cooperation (Shenkar and Zeira, 1992; Luo, 2002), the definition of processes by which exchanges will occur and any disputes will be resolved (Reuer and Ariño, 2007). Contractual safeguards further may specify procedures for monitoring and penalties for noncompliance, and, hence, promote longevity in exchanges (Poppo and Zenger, 2002). Additionally, contractual safeguards may specify rights to reports of relevant transactions between partners and rights for notifications about departures from the agreement (Reuer and Ariño, 2007). In their conceptual work about cooperative LSP networks, Klaas-Wissing and Albers (2010) emphasize the role of contractual safeguarding for establishing incentives and penalties within in the cooperation. Correspondingly, Verstrepen et al. (2009) include contractual safeguarding as a major aspect in their conceptual framework for managing horizontal cooperations in logistics. According to Verstrepen et al. (2009), many LSPs do not sufficiently employ contractual safeguards, and can, therefore, get severe problems with their partners. For example, when partners fail in reaching pre-defined target levels for key performance indicators, conflicts are likely to arise. Upon-agreed contractual safeguards, which specify the expected outcomes and penalties for failing to fulfill these, provide a base to soundly resolve such conflicts.

\section{The outcome of LSP cooperations}

Different approaches to assess the outcome a cooperation yields for the individual firm can be found in the literature (Kale et al., 2002; Nielsen and Nielsen, 2009; Perry et al., 2004; Zacharia et al., 2009). The essential question this comes down to is: how does the firm (expect to) benefit from the cooperation with respect to its own performance? Here, two essential ways of benefiting can be distinguished.

On the one hand, firms can access tangible resources, which are directly exploitable (e.g., efficient and effective organized common transportation networks) and in that way directly improve firm performance in terms of market success and profitability (Kogut, 1988; Cruijssen et al., 2007c). On the other hand, firms can access intangible resources, which are not directly exploitable (e.g., know-how and information) (Simonin, 1997; Kale et al., 2000; Kale and Singh, 2007) and in that way create a basis that indirectly will enhance firm performance. Consequently, we assess the outcome of cooperations from two perspectives.

We term the first perspective cooperation-based firm performance. It refers to the extent to which tangible benefits from the cooperation foster the strategic and financial performance of the involved LSP. While an assessment of pure financial effects may be desired in this perspective, a corresponding measurement is difficult, as the financial effects of a cooperation are not directly observable and often very complex to isolate (Saxton, 1997; Gulati, 1998). In contrast, cooperation-based firm performance is an established comprehensive perspective (Perry et al., 2004), which reflects whether the cooperation has improved the firms competitive position through increased market success and profitability (Kale et al., 2002; Perry et al., 2004). For example, increased cooperation-based firm performance can 
derive from better market penetration through offering customers a greater geographical coverage by combining transportation networks of cooperation partners.

The second perspective refers to the LSP learning via and from the cooperation. We will term this domain cooperation-based learning. It is one of the major motives behind cooperative strategies of firms in general (Doz and Hamel, 1998) and refers to the extent to which intangible resources like know-how and information can be adopted from cooperation partners (Kogut, 1988). By carrying out cooperation activities together and getting involved in the partners' business processes, LSPs are able to identify and adopt critical know-how and information from their partners. This information and know-how, in turn, can indirectly also lead to a competitive advantage for the individual LSP (Porter, 1986; Lane et al., 2001), as it can be applied in the focal firm's activities apart from the respective cooperation. For example, the new skills and capabilities can enhance operational and management processes of the focal LSP. Correspondingly, cooperation-based learning covers the adoption of know-how and information in different fields as technological expertise, service development and delivery, as well as management practices and tools (Kale et al., 2000).

\section{Conceptual model and hypotheses development}

Based on the aforementioned introduction of the two types of operational governance in horizontal LSP cooperations and the two dimensions of cooperation outcome, this section develops a conceptual model (see Figure 1). Two base hypotheses (H1a/b and H2a/b) regarding the link from operational governance to cooperation outcome are derived. They serve as basis for the subsequent conceptualization of the interplay of operational governance with contractual governance. For this interplay, two hypotheses $(\mathrm{H} 3 \mathrm{a} / \mathrm{b}$ and $\mathrm{H} 4 \mathrm{a} / \mathrm{b})$ are developed which outline contractual safeguarding as a moderating factor for the link from operational governance to cooperation outcome. Finally, the relationship between the two outcome dimensions is hypothesized (H5).

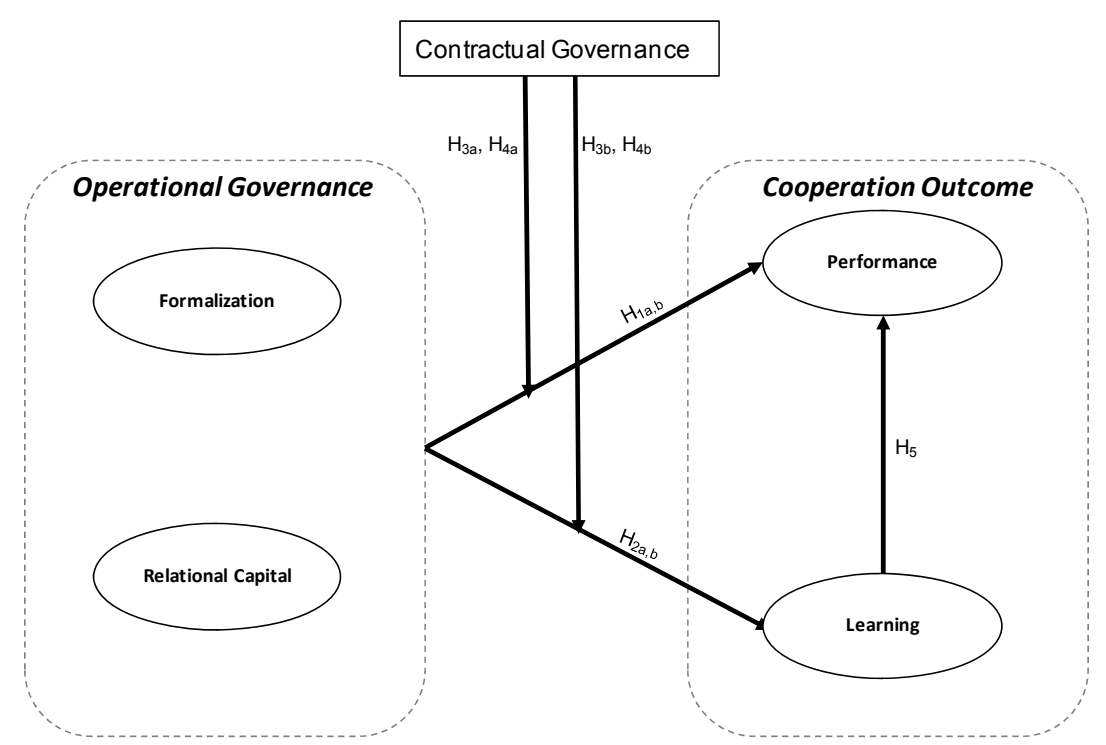

Figure 1: Conceptual model 


\section{The operational governance - cooperation outcome link}

In the following, the effect of process formalization and relational capital on both outcome dimensions is outlined. For cooperation-based firm performance, this influence is outlined from a transaction cost economics perspective, and, for cooperation-based learning, from a perspective of know-how and information exchange.

Transaction cost economics builds on exchange parties that are rationally bounded and exhibit opportunistic self-interest seeking behavior (Williamson, 1975). The exchange between these parties is optimized by applying appropriate governance mechanisms (Williamson, 1985), which help to better coordinate the exchange and reduce opportunistic behavior, and, thus, reduce transaction costs. Whereas initial research on governance in cooperations, which was based on transaction cost economics, focused only on formal types of operational governance mechanisms (Williamson, 1991), later works have shown that also relational types of operational governance mechanisms are effective in limiting transaction costs (Gulati, 1995; Kale et al., 2000), and current research considers both types of operational governance (Judge and Dooley, 2006; Hoetker and Mellewigt, 2009). To reduce transaction costs, partners may use both, process formalization as a mechanism of the formal type of operational governance and relational capital as a mechanism of the relational type of operational governance (Lee and Cavusgil, 2006; Zollo et al., 2002; Luo, 2002).

Process formalization improves the coordination of horizontal LSP cooperations (Schmoltzi and Wallenburg, 2012). It allows for higher efficiency (Murray and Kotabe, 2005), higher information processing capacity (Galbraith, 1973), better utilization of the involved assets, and higher speed of cooperation processes (Galbraith, 1973). Moreover, it identifies complementary tasks and responsibilities and, by doing so, puts limits on the actions of cooperation partners and enhances possibilities to monitor the behavior of partners. This, in turn, makes opportunism less rewarding (Dwyer and Oh, 1987; Dahlstrom and Nygaard, 1999), and, thus, lowers transaction costs (Hoetker and Mellewigt, 2009).

Relational capital "involves the pattern of interaction between partner firms that facilitates and allows for the effective functioning of [cooperations] on a day-to-day basis" (Cullen et al., 2000, p. 224). In particular, it allows partners to better understand the common goals of the cooperation partners, and, thus, improves mutual decision making and cooperation coordination (Stephen and Coote, 2007). Accordingly, Schmoltzi and Wallenburg (2012) stress that coordination in horizontal LSP cooperations is positively affected by mutual decisionmaking whereas missing mutuality amplifies opportunistic behavior. Relational capital creates an atmosphere of mutual confidence in which the exchange parties will not exploit the others' vulnerabilities even if there is an opportunity to do so (Sabel, 1993, Kale et al., 2000; Kumar et al., 2011). Therefore, it lowers the need for monitoring which reduces transaction costs (Gulati 1995).

The two domains, improved coordination and reduced opportunism lower the transaction costs and, thus, enhance its efficiency and effectiveness, what constitutes a tangible and directly exploitable benefit to each company. It is likely to foster the strategic and financial performance, as it increases market strength and profitability of the cooperating LSPs. Consequently, we conclude:

H1a: Process formalization has a positive influence on cooperation-based firm performance.

H1b: Relational capital has a positive influence on cooperation-based firm performance.

This article is (C) Emerald Group Publishing and permission has been granted for this version to appear here

(http://www.cbs.dk/). Emerald does not grant permission for this article to be further copied/distributed or hosted elsewhere without the express permission from Emerald Group Publishing Limited. 
The two operational governance mechanisms, process formalization and relational capital, also positively influence cooperation-based learning.

Cooperation-based learning consists of the acquisition of: (a) information and (b) know-how (Kogut and Zander, 1992; Kale et al., 2000). Information is easily codifiable knowledge that can be transmitted, when the syntactical rules required for deciphering it are known and includes facts, axiomatic propositions, and symbols (Kale et al., 2000). Contrasting this, know-how consists of knowledge that is tacit, sticky, complex, and difficult to codify (Nelson and Winter, 1982; Szulanski, 1996; Kale et al., 2000) and is an accumulated practical skill or expertise (von Hippel, 1988).

Learning usually takes place when cooperation partners carry out their cooperation activities together. Here, operational governance mechanisms enhance cooperation-based learning to the extent to which they facilitate the exchange of information and know-how. Process formalization facilitates the exchange of information and extends information-processing capacity (Galbraith, 1973; Steinicke et al., 2012), and, thus, enhances learning between cooperation partners through increased coordination. Process formalization further leads to greater openness between cooperation partners when it is set up, as partners dealing with sensitive information and know-how are encouraged to open up (Steinicke et al., 2012) and reveal further details of their internal processes (Daugherty et al., 2011), which can be adopted by cooperation partners. Thus, it also increases learning through reduced opportunism.

Relational capital also enhances cooperation-based learning, as it facilitates the exchange of information. In particular, relational capital is associated with higher intensity, frequency, and breadth of the exchange of business-related information (Larson, 1992), and greater know-how acquisition (Yli-Renko et al., 2001). Additionally, relational capital leads to a more intense exchange of know-how. Particularly, relational capital lowers the perception of the risk of opportunism, which makes cooperation partners more confident to share information and knowledge and to engage in wide-ranging, continuous and intense knowledge sharing (Kale et al., 2000; Bosch-Sijtsema and Postma, 2010). Consequently, we hypothesize:

\section{H2a: Process formalization has a positive influence on cooperation-based learning.}

H2b: Relational capital has a positive influence on cooperation-based learning.

\section{The interplay of contractual and operational governance}

Not only operational but also contractual governance mechanisms have the main functions of enhancing coordination ( $\mathrm{Li}$ et al., 2010) and reducing opportunism between cooperation partners (Heide, 1994).

Still no research results exist regarding the question whether contractual safeguarding is either able to substitute or complement the formal type of operational governance. We outline, contractual safeguarding to be able to substitute process formalization in improving cooperation coordination and reducing opportunism between cooperation partners. With respect to cooperation-based firm performance, contractual safeguarding is like process formalization - able to improve coordination through better-organized information processing. In particular, contractual safeguards specify rights to report of relevant transactions between partners and rights for notifications about departures from the agreement, and, thereby, facilitate the coordination of cooperation activities (Reuer and Ariño, 2007). In the same vein, Poppo and Zenger (2002) conceptualize that cooperation contracts improve cooperation coordination - like process formalization - through the 
specification of procedures. For example, the access of information from the cooperation partners could be realized through process formalization in form of standard operating procedures as well as through clauses in the cooperation contract which contain the rights to reports of relevant transactions and notifications of departures from the contractual agreement. Additionally, contractual safeguards are - like process formalization - able to reduce opportunism by specifying the responsibilities and tasks of the partners in a cooperation (Reuer and Ariño, 2007). In doing so, they also limit the actions of cooperation partners and enhance the possibility to monitor for opportunistic behavior, which, in turn, becomes less promising. Therefore, contractual safeguards also lower transaction costs and improve cooperation-based firm performance. Consequently, contractual safeguarding is expected to, at least partly, substitute the positive effect of process formalization on cooperation-based firm performance.

With respect to cooperation-based learning, a similar pattern can be derived. Like process formalization, contractual safeguarding is able to coordinate the flow of information (Reuer and Arino, 2007) as the first of the two types of knowledge relevant to cooperationbased learning. This reasoning is supported by findings of Steinicke et al. (2012), who empirically show that LSPs can - when striving for innovative outcomes - replace process formalization with equity involvement associated with more formalized coordination. Moreover, setting up contractual safeguards - like process formalization - encourages the cooperating parties to open up. Thus, when being set up, contractual safeguarding also allows partners insights into each other's sensitive information and know-how. For example, when the exchange relationship is specified for the contract, LSPs might gain insight into the technologies cooperation partners are using. Therefore, contractual safeguarding is hypothesized to, at least partly, substitute the cooperation-based learning increasing effect of process formalization.

H3a: The positive influence of process formalization on cooperation-based firm performance decreases when the degree of contractual safeguarding increases.

H3b: The positive influence of process formalization on cooperation-based learning decreases when the degree of contractual safeguarding increases.

Several research works have dealt with the relationship between contractual safeguarding and the relational type of operational governance (Bradach and Eccles, 1989; Gulati, 1995; Poppo and Zenger, 2002; Aalbers, 2010; Wang et al., 2011). For the case of horizontal LSP cooperations, we propose contractual safeguarding to complement the positive influence of relational capital on cooperation outcome, and, thus, follow the second of the two above introduced schools of thought. Puranam and Vanneste (2009) suggest that contractual governance and the relational type of operational governance complement each other in complex cooperation settings with unforeseeable contingencies and high uncertainty and volatility. Horizontal LSP cooperations fulfill these criteria, as they are complex involving many partners and business functions as well as having an international reach (Schmoltzi and Wallenburg, 2011). Moreover, Steinicke et al. (2012) emphasize that LSP cooperations are - in contrast to manufacturing cooperations - more complex to govern due to the key role of the customer in the service delivery process and the difficulty of protecting proprietary knowledge.

In particular, contractual safeguarding is an effective complementary measure to overcome a major limitation of relational capital in reducing opportunism (Poppo and Zenger, 2002). This limitation is the lacking security of repeated exchanges that 
is necessary for the relational type of operational governance to become effective (Klein, 1996; Baker et al., 2002). Only when the exchange partners are sure about the longevity of a complex cooperation, good personal relationships and trust will encourage them to invest in the cooperation, and, thus, in its long-term success. In contrast, when it is unclear whether repeated future exchanges will take place, exchange partners may better behave opportunistically and pursue short-term gains instead, as possible future pay-offs only are vague. Contractual safeguarding provides this security, as partners agree to a binding long-term commitment and even specify legally enforceable punishments, and, thus, it lowers the attractiveness of opportunistic behavior. Hence, contractual safeguarding overcomes this limit of relational capital, and, therefore, is likely to complement its transaction cost reducing effect which increases cooperation-based firm performance.

Contractual safeguarding also complements the positive effect of relational capital on cooperation-based learning in a similar manner. Repeated exchanges and stable, long-term relationships are a precondition for cooperation-based learning (Beamish and Banks, 1987, Lane et al., 2001), as successful learning "rests upon an iterative process of exchange between the member firms and the extent to which personnel from the two firms have direct and intimate contact to further an exchange" (Arrow, 1974; Badaracco, 1991 in Kale et al., 2000, p. 221). For example, when an LSP is learning from its partners in complex fields such as how to provide higher quality in service delivery, a continuously lasting exchange with these partners is necessary to adopt all relevant aspects. Contractual safeguarding is effective in ensuring this longevity of a cooperation, as partners agree to a binding long-term commitment, and, therefore, complements relational capital in facilitating cooperation-based learning.

H4a: The positive influence of relational capital on cooperation-based firm performance increases when the degree of contractual safeguarding increases.

H4b: The positive influence of relational capital on cooperation-based learning increases when the degree of contractual safeguarding is increases.

\section{Interrelation of outcome dimensions}

The (intangible) know-how and information adopted from cooperation partners through cooperation-based learning can be turned into tangible benefits, and, thus, positively affects cooperation-based firm performance (Leonard-Barton, 1998; Zahra et al., 2000; Nielsen and Nielsen, 2009), particularly, for two main reasons. First, the adopted knowledge (know-how and information) provides a basis for the development of innovations within LSPs (Chapman et al., 2003). Such innovations have been proven to enable business organizations to gain competitive advantages necessary to compete in their markets (Kandampully, 2002; Dilk et al., 2008; Defee and Fugate, 2010; Daugherty et al., 2011), as innovative organizations are able to adapt to new economical challenges and changes in customer demand more easily (Grawe, 2009; Grawe et al., 2009; Gunday et al., 2011). Second, the adopted know-how can often be directly applied in the focal firm's processes and lead to tangible benefits, e.g., reduced cycle times, improved order fulfillment, external partnering capabilities, and stronger management competencies (Celuch et al., 2002; Panayides, 2007), which, in turn, will increase profitability and market success.

H5: Cooperation-based learning has a positive influence on cooperation-based firm performance. 


\section{Methodology}

\section{Sampling and data collection}

The data for hypotheses testing was collected with a web-based survey. The questionnaire was sent to executive managers of LSPs, who can be assumed to be well qualified as informants because horizontal LSP cooperations mostly lay in the responsibility of the topmanagement. Corresponding to the crucial role of cooperation contracts in our research model, the survey was addressed to respondents in a country with legal enforceability. In particular, the sample was drawn from a commercial company database containing German firms with an annual turnover of more than 1 million euros. Overall, we could obtain valid email addresses for 3,661 LSPs with legal entities in Germany, which received an invitation with a personalized link to the questionnaire. We received 389 responses, a response rate of $10.6 \%$. Of those, 160 responses originate from LSPs that did not cooperate horizontally with other LSPs, whereas 229 responses originate from LSPs with relevant cooperation experience this share of $59 \%$ cooperating LSPs is consistent with the share identified by Schmoltzi and Wallenburg (2011). Due to our research aim, the responses from non-cooperating LSPs could not be used for hypotheses testing. Of the remaining 229 datasets, 20 were deleted because of incomplete data leaving 209 sets for further analysis (see Table 1).

To test for potential non-response bias, company demographics of responding firms were compared to those of the non-responding ones using available data from the company database (Wagner and Kemmerling, 2010). To test for potential late-response bias, survey data from the earliest third of respondents was compared to the latest third (Armstrong and Overton, 1977). For both, no significant differences between the groups were found, indicating that non-response is of no concern.

Since we applied a single source approach, we designed the survey to reduce common-method bias by arranging the survey question in an order, which does not allow for conclusions about the research model. In addition, respondents' anonymity was warranted and in the questionnaire it was stressed out that no wrong

$\begin{array}{lcc}\text { Sales revenue (in } € \text { ) } & \mathbf{n} & \mathbf{\%} \\ 1-5 \text { million } & 58 & 27.7 \\ >5-25 \text { million } & 61 & 29.2 \\ >25-100 \text { million } & 42 & 20.1 \\ >100-500 \text { million } & 23 & 11.0 \\ >500 \text { million-5 billion } & 7 & 3.3 \\ >5 \text { billion } & 5 & 2.4 \\ \text { Not specified } & 13 & 6.3 \\ \text { Total } & \mathbf{2 0 9} & \mathbf{1 0 0} \\ & & \\ \text { Number of employees } & \mathbf{n} & \mathbf{2} \\ 1-50 & 72 & 34.4 \\ 51-100 & 38 & 18.3 \\ 101-500 & 63 & 30.1 \\ 501-1000 & 9 & 4.3 \\ >1000 & 19 & 9.1 \\ \text { Not specified } & 8 & 3.8 \\ \text { Total } & \mathbf{2 0 9} & \mathbf{1 0 0}\end{array}$

Table 1: Firm demographics of respondents 
answers exist. We further tested for the presence of common-method bias by using a theoretically uncorrelated marker variable (Podsakoff et al., 2003). The lowest correlation of this variable to the other items is 0.005 ( $\mathrm{p}>0.938$ ), representing the upper bound for a potential common-method variance. This indicates that also common-method bias is of no concern in our study.

\section{Measurement models}

Construct measurement relied upon multi-item 7-point scales derived from logistics and strategic management literature. They were pretested with six logistics researchers and six executive managers of LSPs to ensure face validity.

Cooperation-based firm performance was measured based on the performance scales of Perry et al. (2004) reflecting to what extent the cooperation resulted in a better competitive position and increased profitability of the focal firm. For assessing cooperation-based learning, we referred to the scale of Lane et al. (2001), measuring to what extent firms have learned from their partners. Process formalization was measured using the formalization scale of Murray and Kotabe (2005) from which one item was eliminated in the scale refinement process. Relational capital was assessed based on the scale of Kale et al. (2000).

To capture the degree of contractual safeguarding, we used a measure of contractual provisions developed by Parkhe (1993). Specifically, he developed a list of eight contractual safeguards based on legal literature. Respondents in our study were asked to indicate for each item whether this contractual provision is applied in the specific cooperation. For testing the interplay of governance via multi-group analysis, the sample was divided into two subgroups: a low contractual safeguarding group that applied the half or less of these eight safeguards $(\mathrm{N}$ $=67$ ), and a high contractual safeguarding group that applied more than half of these eight safeguards $(\mathrm{N}=142)$.

Empirical research relies on measurement models that are both reliable and valid. Scale reliability and validity were assessed using SPSS 20 and Amos 20. All Cronbach's alpha values were well above the suggested 0.7 (Nunnally and Bernstein, 1978). In addition, the confirmatory factor analysis showed good model fit: $\chi^{2} / \mathrm{df}=1.876, \mathrm{CFI}=0.965$, TLI $=0.953$ and RMSEA $=0.065$. All factor loadings are significant at $\mathrm{p}<0.001$, supporting convergent validity. Further, for all constructs, the Fornell and Larcker (1981) criterion indicates discriminant validity, as results show that all AVEs surpass the respective squared correlations. All measurement models used in the questionnaire can be found in the Appendix.

\section{Hypotheses test results}

Our model provides good fit between theory and empirical data: The fit of the structural base model indicates adequate model fit $\left(\chi^{2} / \mathrm{df}=1.876, \mathrm{CFI}=0.965, \mathrm{TLI}=0.953, \mathrm{RMSEA}=\right.$ $0.065)$.

As displayed in Figure 2, H1a,b find support, as process formalization $(+0.29, \mathrm{p}<$ $0.001)$ and relational capital $(+0.39, \mathrm{p}<0.001)$ have significant positive effects on cooperation-based firm performance. Also H2a,b find support as process formalization $(+0.34, \mathrm{p}<$ $0.001)$ and relational capital $(+0.32, \mathrm{p}<0.001)$ have a significantly positive influence cooperation-based learning. Cooperation-based learning has a significant positive effect on cooperation-based firm performance $(+0.32, \mathrm{p}<0.001)$ providing support for $\mathrm{H} 5$. 


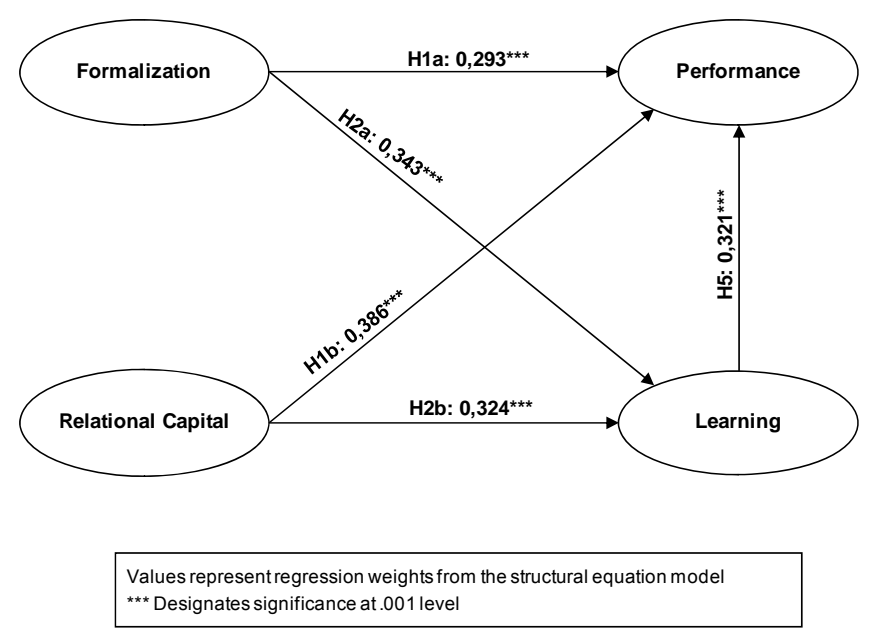

Figure 2: Empirical results for hypothesized base model

The explanatory power of the model is substantial, as the variance explained $\left(\mathrm{R}^{2}\right)$ is $68.0 \%$ for cooperation-based firm performance and $15.4 \%$ for cooperation-based learning.

To identify the moderating effects of contractual safeguarding, a multi-group analysis was conducted. All parameters of the structural model were estimated separately for the two subsamples under scrutiny and moderation was examined by conducting t-tests to verify the significance of differences between the structural paths. Table 2 contains the results of the moderation analysis. The results presented in this table indicates that, $\mathrm{H} 3 \mathrm{a}$ and $\mathrm{H} 3 \mathrm{~b}$ find only partial support, as the effect of process formalization on cooperation-based firm performance is significantly stronger in settings of low contractual safeguarding $(p<0.001)$ compared to settings where contractual safeguarding is high. At the same time, the effect of process formalization on cooperation-based firm learning is significantly stronger in settings of high contractual safeguarding $(\mathrm{p}<0.001)$ compared to settings where contractual safeguarding is low. Thus, $\mathrm{H} 3 \mathrm{a}$ is supported whereas $\mathrm{H} 3 \mathrm{~b}$ has to be rejected. Consistent with $\mathrm{H} 4 \mathrm{a}$ and $\mathrm{H} 4 \mathrm{~b}$, the effects of relational capital on cooperation-based firm performance $(\mathrm{p}<0.001)$ and cooperation-based learning $(\mathrm{p}<0.001)$ are significantly stronger in settings of high contractual safeguarding compared to settings of low contractual safeguarding, providing support for H4a and $\mathrm{H} 4 \mathrm{~b}$.

\begin{tabular}{lllll} 
& $\begin{array}{l}\text { Low } \\
(\mathrm{n}=67)\end{array}$ & $\begin{array}{l}\text { High } \\
(\mathrm{n}=142)\end{array}$ & \\
\hline Contractual safeguarding & $\begin{array}{l}\text { Standardized } \\
\text { path coefficient }\end{array}$ & $\begin{array}{l}\text { Significance of difference } \\
\text { in path coefficient }\end{array}$ & Hypothesis \\
\hline Formalization $\rightarrow$ performance (H3a) & $0.42^{* *}$ & $0.19^{*}$ & $\mathrm{p}<0.001$ & Support \\
Formalization $\rightarrow$ learning (H3b) & $0.07 \mathrm{n} . \mathrm{s}$. & $0.30^{* * *}$ & $\mathrm{p}<0.001$ & Reject \\
Rel. capital $\rightarrow$ performance (H4a) & $0.28^{*}$ & $0.40^{* * *}$ & $\mathrm{p}<0.001$ & Support \\
Rel. capital $\rightarrow$ learning (H4b) & $0.18 \mathrm{n} . \mathrm{s}$. & $0.39^{* * *}$ & $\mathrm{p}<0.001$ & Support \\
\hline
\end{tabular}

Notes: n.s., Not significant. ${ }^{*}, * *, * * *$ Significant at $0.1,0.01$, and 0.001 levels, respectively

Table 2: Results of moderation analyses for contractual safeguarding 


\section{Discussion}

\section{Theoretical contributions}

Our results reveal a new perspective on the interplay of governance mechanisms in horizontal cooperations. Recent research in the field of governance in cooperations examines the interplay of two distinct governance forms, in particular contractual governance and the relational type of operational governance (Mayer and Argyres, 2004; Reuer and Ariño, 2007). Here, two different schools have emerged among cooperation management scholars (Kale and Singh, 2009), of which the first school suggests that contractual safeguarding and the relational type of operational governance substitute or crowd out each other (Bradach and Eccles, 1989; Gulati, 1995; Wang et al., 2011), whereas the second school emphasizes contractual safeguarding and the relational type of operational governance to be complementary (Poppo and Zenger, 2002; Aalbers, 2010).

Our research not only clarifies this interplay of governance mechanisms for the case of LSP cooperations, but draws a more comprehensive picture by extending the view on governance in cooperations in two ways. First, unlike in most of the previous research contributions, we not only limit our research to the relational type of operational governance, but follow Wallenburg and Raue (2011) and extend the view to a second type: a formal type of operational governance, and contrast the effectiveness of these two types of operational governance with the level of contractual governance applied. Second, when examining the interplay between operational and contractual governance, this research goes beyond identifying whether these governance forms are in use at the same time. Rather, it is first in building upon the outcome effects that originate from the combination of contractual and operational governance mechanisms and is, therefore, responsive to Reuer and Ariño's (2007) call for further research.

To examine and explain the interplay of operational and contractual governance, this research illustrates and draws upon the underlying levers through which governance in cooperations affects cooperation outcome. Both forms of governance affect cooperation outcome through the same two main levers: On the one hand, they facilitate the coordination of cooperations, and, on the other hand, they reduce the risk of opportunistic behavior between cooperation partners.

This research shows how contractual safeguarding influences the effectiveness of operational governance mechanisms in increasing cooperation-based firm performance as well as cooperation-based learning.

(1) With respect to cooperation-based firm performance, contractual safeguarding is able to partly substitute the coordination facilitating and the opportunism reducing functions of process formalization. At the same time, contractual safeguarding complements the opportunism reducing function of relational capital. Consequently, with respect to cooperation-based firm performance, our results for LSP cooperations correspond to the second of the two schools of thought concerning the interplay between contractual governance and the relational type of operational governance, leading to more clarity in this discussion. Furthermore, our result correspond to Puranam and Vanneste (2009) who suggest a complementing effect particularly in uncertain and complex cooperation settings - a criterion which LSP cooperations fulfill (Schmoltzi and Wallenburg, 2011). Contrasting this, our findings contradict Gulati (1995) who identify the relational type of operational governance to substitute contractual governance.

This article is (C) Emerald Group Publishing and permission has been granted for this version to appear here (http://www.cbs.dk/). Emerald does not grant permission for this article to be further copied/distributed or hosted elsewhere without the express permission from Emerald Group Publishing Limited. 
(2) With respect to cooperation-based learning, contrary to our expectations, process formalization is not substituted by contractual safeguarding, but rather complemented. Only when contractual safeguarding is high, process formalization increases cooperation-based learning significantly. Apparently, contractual safeguarding is necessary for process formalization to improve the exchange of know-how and information between cooperation partners. This exchange particularly takes place, when process formalization is jointly set up by the cooperation partners. During this set-up of process formalization, security about the longevity of the cooperation and future exchanges decrease the risk that partners will use sensitive information and know-how to one's own disadvantage. It rather encourages partners to open up and exchange sensitive information and know-how when establishing process formalization for cooperation processes. Besides, contractual safeguarding also complements relational capital in increasing cooperation-based learning. Consequently, also with respect to the second outcome dimension, cooperation-based learning, our results for LSP cooperations correspond to the second school concerning the interplay of contractual governance and the relational type of operational governance, and confirm, e.g., Cannon et al. (2000) who argue that contractual governance strengthens information exchange through relational mechanisms. Our findings contrast the findings of Wang et al. (2011) who identified contractual governance and the relational type of operational governance to substitute each other when cooperations strive for innovative outcomes.

Thus, these results have drawn a comprehensive and clear picture of the interplay of contractual governance and two types of operational governance and build upon the outcome effects that originate from these combinations. Thereby, they make a theoretical contribution by bringing clarity to a long lasting discussion between scholars of two opposing schools of thought.

As expected, cooperation-based learning is a driver for cooperation-based firm performance. This result extends the findings of Shang (2009), who finds a positive effect of learning capabilities on performance of LSPs, to the context of horizontal LSP cooperations.

\section{Managerial implications}

Our results provide guidance for managers of horizontal cooperations between LSPs, who strive for establishing governance mechanisms. Implementing an efficient governance structure is one of the most important tasks of cooperation managers (Kale and Singh, 2009). When considering the potential losses through implementing inefficient combinations of governance mechanisms, a profound knowledge about its outcome effects and its interplay with other governance mechanisms is of high value for cooperation managers. From our results, it can be concluded whether operational governance mechanisms (i.e., process formalization and relational capital) can be substituted or complemented by contractual safeguarding. Therefore, it allows managers to better understand what has been a blackbox so far: investing efficiently into the right set of governance mechanisms.

Many LSPs join a horizontal cooperation to access tangible resources which are directly exploitable (e.g., well organized common transportation networks or warehouse infrastructure) and directly contribute to the LSP's firm performance. In such cases, process formalization and contractual safeguarding are substitutes. Consequently, 
LSPs can choose whether to rely on extensive contracts or on elaborated process formalization in order to improve coordination and reduce opportunism. This is an interesting finding, as managers of LSPs are enabled to make a strategic decision, but this decision will depend on situational aspects carefully to be taken into account. For example, when establishing an international transportation network with LSPs from several countries with several legal systems involved, it might be much cheaper to extend process formalization (e.g., handbooks and standard operating procedures) than increasing the complexity of contracts by involving many lawyers from the respective countries, in order to develop extensive contractual safeguards.

Contrasting this, our results show that process formalization and contractual safeguards are complements when cooperating LSPs aim at accessing intangible resources, which are not directly exploitable, e.g., know-how and information, and provide the basis for future firm performance. LSPs particularly learn from cooperation partners, when establishing or refining process formalization together. Here, the longevity of the cooperation ensured by contractual safeguarding leads cooperation partners to open up and share sensitive information and know-how with their partners. In consequence, LSPs striving to learn from their partners when developing process formalization provide confidence to their partners through wellspecified cooperation contracts.

Our results further provide cooperation managers with clear answers about the interplay of relational capital and contractual safeguarding. Contractual safeguarding complements relational capital as a facilitator of coordination and a reducer of opportunism, irrespective of whether the LSPs expect tangible or intangible benefits from the cooperation. Through high contractual safeguarding, LSPs ensure longevity of their cooperation, and, thus, provide security that future exchanges will take place. In doing so, they overcome a major limit of relational capital: the lacking security of future exchanges. Thus, managers striving for increased coordination and reduced opportunism through relational capital can rely on the complementing effect of contractual safeguarding as an effective measure.

This study also helps managers to understand the role of cooperation-based learning for cooperation-based firm performance. By accessing intangible resources like information and know-how, LSPs build a foundation for future tangible benefits like new developed services or improved operational processes. Consequently, LSP managers only seeking after tangible benefits from cooperations, should consider learning and the access to intangible resources as an intermediate step to realize tangible benefits, and, thus, as a driver for cooperation-based firm performance.

\section{Limitations and future research}

This study has some limitations, which may be addressed in future research. First, the effectiveness of contractual safeguarding depends on the legal systems. In countries, in which it is more difficult for a firm to enforce its rights, contracts are likely to be less effective than in Germany, where the survey data was collected. Accordingly, future research comparing our findings with the interplay of contractual governance and operational governance in countries with different legal systems would be valuable.

Second, the effectiveness of relational capital depends on the behavior of the involved people and is likely to depend on the respective cultural environments. In countries where organizations are characterized by more hierarchy and where employees are stronger oriented towards their top management and less independent, it

might be more difficult to develop relational capital between competing firms in 
horizontal cooperations. Therefore, additional research clarifying the effectiveness of relational capital as an operational governance mechanism in horizontal cooperations in other cultural environments will be useful.

Third, in our research, we focus on process formalization as a mechanism of the formal type of operational governance. To get a more comprehensive understanding of the formal type of operational governance, we encourage further research about this type. In particular, the measurement of cooperation performance through formalized procedures is a promising field of research.

Finally, our study investigates governance in cooperations as an important lever to deal with opportunism between cooperation partners. Apart from governance, also the behavior of cooperations partners in situations of disputes is crucial to the extent of opportunism existent between cooperation partners. Future studies addressing the effectiveness of possible conflict management strategies to cope with opportunism will be of high value for both, researchers and practitioners.

\section{References}

Aalbers, R. (2010), "The role of contracts and trust in R\&D alliances in the Dutch biotech sector", Innovation: Management, Policy \& Practice, Vol. 12 No. 3, pp. 311-329.

Armstrong, J.S. and Overton, T.S. (1977), "Estimating nonresponse bias in mail surveys", Journal of Marketing Research (JMR), Vol. 14 No. 3, pp. 396-402.

Arrow, K. J. (1974), The Limits of Organization. Norton, New York.

Badaracco, J. L. (1991), The Knowledge Link. Harvard Business School Press, Boston, MA.

Baker, G., Gibbons, R. and Murphy, K.J. (2002), "Relational contracts and the theory of the firm", Quarterly Journal of Economics, Vol. 117 No. 1, pp. 39-84.

Bengtsson, M. and Kock, S. (2000), "Cooperation' in Business Networks-to Cooperate and Compete Simultaneously”, Industrial Marketing Management, Vol. 29 No. 5, pp. 411427.

Bosch-Sijtsema, P.M. and Postma, T.J.B.M. (2010), "Governance factors enabling knowledge transfer in interorganisational development projects", Technology Analysis \& Strategic Management, Vol. 22 No. 5, pp. 593-608.

Bradach, J.L. and Eccles, R.G. (1989), "Price, authority, and trust: from ideal types to plural forms", Annual Review of Sociology, Vol. 15 No. 1, pp. 97-118.

Braziotis, C. and Tannock, J. (2011), "Building the extended enterprise: key collaboration factors", International Journal of Logistics Management, Vol. 22 No. 3, pp. 349-372.

Cannon, J., Achrol, R. and Gundlach, G. (2000), "Contracts, norms, and plural form governance", Journal of the Academy of Marketing Science, Vol. 28 No. 2, pp. 180-194.

Carbone, V. and Stone, M.A. (2005), "Growth and relational strategies used by the European logistics service providers: rationale and outcomes", Transportation Research: Part E, Vol. 41 No. 6, pp. 495-510.

Celuch, K.G., Kasouf, C.J. and Peruvemba, V. (2002), "The effects of perceived market and learning orientation on assessed organizational capabilities", Industrial Marketing Management, Vol. 31 No. 6, pp. 545-554.

Chapman, R.L., Soosay, C. and Kandampully, J. (2003), "Innovation in logistic services and the new business model: a conceptual framework", International Journal of Physical Distribution \& Logistics Management, Vol. 33 No. 7, pp. 630-650.

Cruijssen, F., Dullaert, W. and Fleuren, H. (2007a), "Horizontal cooperation in transport and logistics: a literature review", Transportation Journal, Vol. 46 No. 3, pp. 22-39. 
Cruijssen, F., Cools, M. and Dullaert, W. (2007b), "Horizontal cooperation in logistics: opportunities and impediments", Transportation Research: Part E, Vol. 43 No. 2, pp. 129-142.

Cruijssen, F., Bräysy, O., Dullaert, W., Fleuren, H. and Salomon, M. (2007c), “Joint Route Planning under Varying Market Conditions", International Journal of Physical Distribution \& Logistics Management, Vol. 37 No. 4, pp. 287-304.

Cullen, J.B., Johnson, J.L. and Sakano, T. (2000), "Success through commitment and trust: the soft side of strategic alliance management", Journal of World Business, Vol. 35 No. 3, pp. 223-240.

Dahlstrom, R. and Nygaard, A. (1999), "An empirical investigation of ex post transaction costs in franchised distribution channels", Journal of Marketing Research (JMR), Vol. 36 No. 2, pp. 160-170.

Das, T.K. and Bing-Sheng, T. (1998), "Between Trust and Control: Developing Confidence in Partner Cooperation in Alliances", Academy of Management Review, Vol. 23 No. 3, pp. 491-512.

Daugherty, P., Chen, H. and Ferrin, B.G. (2011), "Organizational structure and logistics service innovation", International Journal of Logistics Management, Vol. 22 No. 1, pp. 26-51.

Defee, C.C. and Fugate, B.S. (2010), "Changing perspective of capabilities in the dynamic supply chain era”, International Journal of Logistics Management, Vol. 21 No. 2, pp. 180-206.

Dilk, C., Gleich, R., Wald, A. and Motwani, J. (2008), "State and development of innovation networks: evidence from the European vehicle sector", Management Decision, Vol. 46 No. 5, pp. 691-701.

Doz, Y.L. and Hamel, G. (1998), Alliance Advantage: The Art of Creating Value through Partnering, Harvard Business School Press, Boston, MA.

Dwyer, F.R. and Sejo Oh. (1987), "Output sector munificence effects on the internal political economy of marketing channels", Journal of Marketing Research (JMR), Vol. 24 No. 4, pp. 347-358.

Dyer, J.H. and Singh, H. (1998), "The relational view: cooperative strategy and sources of interorganizational competitive advantage", Academy of Management Review, Vol. 23 No. 4, pp. 660-679.

Fornell, C. and Larcker, D.F., (1981), "Evaluating Structural Equation Models with Unobservable Variables and Measurement Error", Journal of Marketing Research (JMR), Vol. 18 No. 1, pp. 39-50.

Fugate, B.S., Davis-Sramek, B. and Goldsby, T.J. (2009), "Operational collaboration between shippers and carriers in the transportation industry", International Journal of Logistics Management, Vol. 20 No. 3, pp. 425-447.

Galbraith, J. R. (1973) Designing Complex Organizations, Addison-Wesley Longman Publishing Co., Inc.

Granovetter, M. (1985), "Economic action and social structure: the problem of embeddedness", The American Journal of Sociology, Vol. 91 No. 3, pp. 481-510.

Grawe, S.J. (2009), "Logistics innovation: a literature-based conceptual framework", International Journal of Logistics Management, Vol. 20 No. 3, pp. 360-377.

Grawe, S.J., Chen, H. and Daugherty, P.J. (2009), "The relationship between strategic orientation, service innovation, and performance", International Journal of Physical Distribution \& Logistics Management, Vol. 39 No. 4, pp. 282-300.

Gulati, R. (1995), "Does familiarity breed trust? The implications of repeated ties for contractual choice in alliances", Academy of Management Journal, Vol. 38 No. 1, pp. 85112. 
Gulati, R. (1998), “Alliances and networks”, Strategic Management Journal, Vol. 19 No. 4, pp. 293-317.

Gunday, G., Ulusoy, G., Kilic, K. and Alpkan, L. (2011), "Effects of innovation types on firm performance", International Journal of Production Economics, Vol. 133 No. 2, pp. 662676.

Hammervoll, T. (2011), "Honeymoons in supply chain relationships: the effects of financial capital, social capital and psychological commitment", International Journal of Logistics Management, Vol. 22 No. 2, pp. 264-279.

Heide, J.B. (1994), "Interorganizational governance in marketing channels", Journal of Marketing, Vol. 58 No. 1, pp. 71-85.

Hoetker, G. and Mellewigt, T. (2009), "Choice and performance of governance mechanisms: matching alliance governance to asset type", Strategic Management Journal, Vol. 30 No. 10, pp. 1025-1044.

Hofenk, D., Schipper, R., Semeijn, J. and Gelderman, C. (2011), "The influence of contractual and relational factors on the effectiveness of third party logistics relationships", Journal of Purchasing and Supply Management, Vol. 17 No. 3, pp. 167-175.

Jap, S.D. and Ganesan, S. (2000), "Control Mechanisms and the Relationship Life Cycle: Implications for Safeguarding Specific Investments and Developing Commitment", Journal of Marketing Research (JMR), Vol. 37 No. 2, pp. 227-245.

Jayaraman, V., Narayanan, S., Luo, Y. and Swaminathan, J.M., (2012). "Offshoring business process services and governance control mechanisms: an examination of service providers from india", Production and Operations Management, in press.

Judge, W.Q. and Dooley, R., (2006), "Strategic alliance outcomes: a transaction-cost economics perspective", British Journal of Management, Vol. 17 No. 1, pp. 23-37.

Kale, P. and Singh, H. (2009), "Managing strategic alliances: what do we know now, and where do we go from here?", Academy of Management Perspectives, Vol. 23 No. 3, pp. 45-62.

Kale, P., Dyer, J.H. and Singh, H. (2002), "Alliance capability, stock market response, and long term alliance success: the role of the alliance function", Strategic Management Journal, Vol. 23 No. 8, pp. 747-767.

Kale, P., Singh, H. and Perlmutter, H. (2000), "Learning and protection of proprietary assets in strategic alliances: building relational capital”, Strategic Management Journal, Vol. 21 No. 3, pp. 217-237.

Kandampully, J. (2002), "Innovation as the core competency of a service organisation: the role of technology, knowledge and networks", European Journal of Innovation Management, Vol. 5 No. 1, pp. 18-26.

Klaas-Wissing, T. and Albers, S. (2010), "Cooperative versus corporate governance of LTL networks", International Journal of Logistics Research and Applications, Vol. 13 No. 6, pp. 493-506.

Klein, B.A. (1996), "Why hold-ups occur: the self-enforcing range of contractual relationships", Economic Inquiry, Vol. 34 No. 3, pp. 444-463.

Kogut, B. (1988), "Joint Ventures: Theoretical and Empirical Perspectives”, Strategic Management Journal, Vol. 9 No. 4, pp. 319-332.

Kogut, B. and Zander, U. (1992), "Knowledge of the firm, combinative capabilities, and the replication of technology", Organization Science, Vol. 3 No. 3, pp. 383-397.

Kumar, A., Heide, J.B. and Wathne, K.H. (2011), "Performance implications of mismatched governance regimes across external and internal relationships", Journal of Marketing, Vol. 75 No. 2, pp. 1-17.

Lado, A.A., Paulraj, A. and Chen, I.J. (2011), "Customer focus, supply-chain relational capabilities and performance: evidence from US manufacturing industries", International Journal of Logistics Management, Vol. 22 No. 2, pp. 202-221. 
Lane, P.J., Salk, J.E. and Lyles, M.A. (2001), “Absorbtive capacity, learning, and performance in international joint ventures", Strategic Management Journal, Vol. 22 No. 12, pp. 11391161.

Larson, A. (1992), "Network dyads in entrepreneurial settings: a study of the governance of exchange relationships", Administrative Science Quarterly, Vol. 37 No. 1, pp. 76-104.

Lee, Y. and Cavusgil, S.T. (2006), "Enhancing alliance performance: the effects of contractualbased versus relational-based governance", Journal of Business Research, Vol. 59 No. 8, pp. 896-905.

Leonard-Barton, D. (1998), Wellsprings of Knowledge: Building and Sustaining the Sources of Innovation, Harvard Business Press.

Li, Y., Xie, E., Teo, H. and Peng, M.W. (2010), "Formal control and social control in domestic and international buyer-supplier relationships", Journal of Operations Management, Vol. 28 No. 4, pp. 333-344.

Luo, Y. (2002), "Contract, cooperation, and performance in international joint ventures", Strategic Management Journal, Vol. 23 No. 10, pp. 903-919.

Mayer, K.J. and Argyres, N.S., (2004), "Learning to contract: Evidence from the personal computer industry", Organization Science, Vol. 15 No. 4, pp. 394-410.

Min, S., Roath, A.S., Daugherty, P.J., Genchev, S.E., Chen, H., Arndt, A.D. and Richey, R.G. (2005), "Supply chain collaboration: what's happening?", International Journal of Logistics Management, Vol. 16 No. 2, pp. 237-256.

Mollenkopf, D., Gibson, A. and Ozanne, L. (2000), "The integration of marketing and logistics functions: an empirical examination of New Zealand firms", Journal of Business Logistics, Vol. 21 No. 2, pp. 89-112.

Muir, M. European Supply Chain Horizontal Collaboration: A brief Analysis of Eyefortransport's Recent Survey, London, 2010.

Murray, J.Y. and Kotabe, M. (2005), "Performance implications of strategic fit between alliance attributes and alliance forms", Journal of Business Research, Vol. 58 No. 11, pp. 1525-1533.

Nelson, R. and S. Winter (1982). An Evolutionary Theory of Economic Change. Belknap Press, Cambridge, MA.

Nielsen, B.B. (2010), "Strategic fit, contractual, and procedural governance in alliances", Journal of Business Research, Vol. 63 No. 7, pp. 682-689.

Nielsen, B.B. and Nielsen, S. (2009), "Learning and innovation in international strategic alliances: an empirical test of the role of trust and tacitness", Journal of Management Studies, Vol. 46 No. 6, pp. 1031-1056.

Nunnally, Jum C. and Ira H. Bernstein (1978), Psychometric Theory, New York, NY: McGrawHill.

Panayides, P. and So, M. (2005), "Logistics service provider-client relationships", Transportation Research Part E: Logistics and Transportation Review, Vol. 41 No. 3, pp. 179-200.

Panayides, P. M. (2007), "Effects of organizational learning in third-party logistics", Journal of Business Logistics, Vol. 28 No. 2, pp. 133-158.

Parkhe, A. (1993), "Strategic alliance structuring: a game theoretic and transaction cost examination of inter-firm cooperation", Academy of Management Journal, Vol. 36 No. 4, pp. 794-829.

Perry, M.L., Sengupta, S. and Krapfel, R. (2004), "Effectiveness of horizontal strategic alliances in technologically uncertain environments: are trust and commitment enough?", Journal of Business Research, Vol. 57 No. 9, pp. 951-956. 
Podsakoff, P.M., MacKenzie, S.B., Lee, J.-Y. and Podsakoff, N.P., (2003), “Common method biases in behavioral research: A critical review of the literature and recommended remedies", Journal of Applied Psychology, Vol. 88 No. 5, pp. 879-903.

Poppo, L. and Zenger, T. (2002), "do formal contracts and relational governance function as substitutes or complements?”, Strategic Management Journal, Vol. 23 No. 8, pp. 707725.

Puranam, P. and Vanneste, B. (2009), "Trust and Governance: Untangling a Tangled Web", Academy of Management Review, Vol. 34 No. 1, pp. 11-31.

Reuer, J.J. and Ariño, A. (2007), "Strategic alliance contracts: dimensions and determinants of contractual complexity", Strategic Management Journal, Vol. 28 No. 3, pp. 313-330.

Ryals, L.J. and Humphries, A.S. (2010), "Efficiency versus value maximisation in comanufacturing relationships", International Journal of Logistics Management, Vol. 21 No. 2, pp. 309-330.

Sabel, C.F. (1993), "Studied trust: building new forms of cooperation in a volatile economy", Human Relations, Vol. 46 No. 9, pp. 1133-1170.

Sambasivan, M., Siew-Phaik, L., Mohamed, Z.A. and Leong, Y.C. (2011), "Impact of interdependence between supply chain partners on strategic alliance outcomes: role of relational capital as a mediating construct", Management Decision, Vol. 49 No. 4, pp. 548-569.

Saxton, T. (1997), "The effects of partner and relationship characteristics on alliance outcomes", Academy of Management Journal, Vol. 40 No. 2, pp. 443-461.

Schmoltzi, C. and Wallenburg, C.M. (2011), "Horizontal cooperations between logistics service providers: motives, structure, performance", International Journal of Physical Distribution \& Logistics Management, Vol. 41 No. 6, pp. 552-575.

Schmoltzi, C. and Wallenburg, C.M. (2012), "Operational governance in horizontal cooperations of logistics service providers: performance effects and the moderating role of cooperation complexity", Journal of Supply Chain Management, Vol. 48 No. 2, pp. 5374.

Selviaridis, K. and Spring, M. (2007), "Third party logistics: a literature review and research agenda", The International Journal of Logistics Management, Vol. 18 No. 1, pp. 125-150.

Şengün, A.E. (2010), "Which type of trust for inter-firm learning?", Industry \& Innovation, Vol. 17 No. 2, pp. 193-213.

Shang, K.C. (2009), "Integration and organisational learning capabilities in third-party logistics providers", Service Industries Journal, Vol. 29 No. 3, pp. 331-343.

Shenkar, O. and Zeira, Y. (1992), "Role Conflict and Role Ambiguity of Chief Executive Officers in International Joint Ventures", Journal of International Business Studies, Vol. 23 No. 1, pp. 55-75.

Simonin, B.L., (1997), "The importance of collaborative know-how: an empirical test of the learning organization", Academy of Management Journal, Vol. 40 No. 5, pp. 1150-1174.

Squire, B., Cousins, P.D. and Brown, S. (2009), "Cooperation and knowledge transfer within buyer-supplier relationships: the moderating properties of trust, relationship duration and supplier performance", British Journal of Management, Vol. 20 No. 4, pp. 461-477.

Steinicke, S., Wallenburg, C.M. and Schmoltzi, C. (2012), "Governing for innovation in horizontal service cooperations", Journal of Service Management, Vol. 23 No. 2, pp. 6-6.

Stephen, A.T. and Coote, L.V. (2007), "Interfirm behavior and goal alignment in relational exchanges", Journal of Business Research, Vol. 60 No. 4, pp. 285-295.

Szulanski, G. (1996), "Exploring internal stickiness: impediments to the transfer of best practice within the firm", Strategic Management Journal, Vol. 17, pp. 27-43. 
Teng, B. and Das, T. (2008), "Governance structure choice in strategic alliances: the roles of alliance objectives, alliance management experience, and international partners", Management Decision, Vol. 46 No. 5, pp. 725-742.

Tsai, W. (2002), "Social Structure of "Coopetition" Within a Multiunit Organization: Coordination, Competition, and Intraorganizational Knowledge Sharing", Organization Science, Vol. 13 No. 2, pp. 179-190.

Verstrepen, S., Cools, M., Cruijssen, F. and Dullaert, W. (2009), "A dynamic framework for managing horizontal cooperation in logistics", International Journal of Logistics Systems and Management, Vol. 5 No. 3-4, pp. 228-248.

von Hippel, E. (1988). The Sources of Innovation. Oxford University Press, New York.

Wagner, S.M. and Kemmerling, R. (2010), "Handling nonresponse in logistics research", Journal of Business Logistics, Vol. 31 No. 2, pp. 357-381.

Wallenburg, C.M. and Raue, J.S. (2011), "Conflict and its governance in horizontal cooperations of logistics service providers", International Journal of Physical Distribution \& Logistics Management, Vol. 41 No. 4, pp. 385-400.

Wang, L., Yeung, J.H.Y. and Zhang, M. (2011), "The impact of trust and contract on innovation performance: the moderating role of environmental uncertainty", International Journal of Production Economics, Vol. 134 No. 1, pp. 114-122.

Williamson, O.E. (1975), Markets and Hierarchies: Analysis and Antitrust Implications: A Study in the Economics of Internal Organization, Free Press, New York.

Williamson O.E. (1985), The Economic Institutions of Capitalism, Free Press, New York.

Williamson O.E. (1991), "Comparative economic organization: the analysis of discrete structural alternatives”, Administrative Science Quarterly, Vol. 36 No. 2, pp. 269-296.

Yazdanparast, A., Manuj, I. and Swartz, S.M. (2010), "Co-creating logistics value: a servicedominant logic perspective”, International Journal of Logistics Management, Vol. 21 No. 3, pp. 375-403.

Yli-Renko, H., Autio, E. and Sapienza, H.J. (2001), "Social capital, knowledge acquisition, and knowledge exploitation in young technology-based firms", Strategic Management Journal, Vol. 22 No. 6/7, pp. 587.

Zacharia, Z.G., Nix, N.W. and Lusch, R.F. (2009), "An analysis of supply chain collaborations and their effect on performance outcomes", Journal of Business Logistics, Vol. 30 No. 2, pp. 101-124.

Zahra, S.A., Ireland, R.D. and Hitt, M.A. (2000), "International expansion by new venture firms: international diversity, mode of market entry, technological learning, and performance", Academy of Management Journal, Vol. 43 No. 5, pp. 925-950.

Zollo, M., Reuer, J.J. and Singh, H. (2002), "Interorganizational routines and performance in strategic alliances”, Organization Science, Vol. 13 No. 6, pp. 701-713. 


\section{Appendix: Measurement scales}

Mean

SD

\begin{tabular}{ll}
\hline Cooperation-based firm performance* (Perry et al., 2004) & \\
\hline Cronbach's alpha $=0.86$ & 1.48 \\
To what extent has the cooperation: & 4.77 \\
Enhanced penetration into existing markets? & 4.76 \\
Increased your market share? & 4.78 \\
Increased your profitability? & 1.51 \\
Cooperation-based learning* (Lane et al., 2001) & \\
Cronbach's alpha $=0.86$
\end{tabular}

To what extent have you learned from your cooperation partners in the following areas:

$3.44 \quad 1.78$

Development of new services

$3.78-1.79$

Service production/delivery

$3.52 \quad 1.75$

Management practices and tools

$3.03 \quad 1.61$

Process formalization* (Murray and Kotabe, 2005)

Gronbach's alpha $=0.89$

In our cooperation we have...

...written documents (e.g., handbooks) that spell out detailed tasks, activities and schedules for the cooperation. 4.33

...detailed standard operating procedures (e.g., rules, policies, forms, etc.) for the processes of the cooperation. $4.55 \quad 2.30$

Relational capital* (Kale, Singh and Perlmutter, 2000)

Cronbach's alpha $=0.83$

The cooperation is characterized by..

$\begin{array}{lrl}\text {...close personal interaction. } & 5.43 & 1.47\end{array}$

$\begin{array}{lr}\text {...personal friendship. } & 4.02\end{array}$

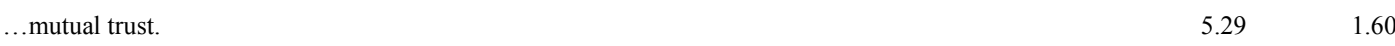

$\begin{array}{lrr}\text {...high reciprocity. } & 4.99 & 1.55\end{array}$

Contractual Safeguarding (Parkhe, 1993; Reuer and Ariño, 2007)

Which of the following safeguards did you include into your cooperation contract?

Rights to reports of relevant transactions

abs. $\quad \%$

Auditing rights

Confidentiality provisions

$87 \quad 41.6$

\begin{tabular}{ll} 
Restrictions on proprietary information & 167 \\
\hline
\end{tabular}

\begin{tabular}{lr} 
Termination provisions & 163 \\
\hline
\end{tabular}

$\begin{array}{lr}\text { Arbitration clauses } & 95 \quad 45.5\end{array}$

$\begin{array}{ll}\text { Lawsuit provisions } & 105 \quad 50.2\end{array}$

*Corresponding items are measured on a 7-point Likert-scale where $1=$ strongly disagree and $7=$ strongly agree

\section{About the authors}

Dr Jan Simon Raue is a Management Consultant at the OC\&C Strategy Consultants. Prior to this post, he was a Research Associate at the Kühne Foundation Center for International Logistics Networks at the Technische Universität Berlin. In addition, he is one of the founders of AdvoAssist, a cooperation platform for lawyers in Germany. His areas of expertise include 
strategic alliances and horizontal cooperations of logistics service providers as well as the management of global supply chains. Jan Simon is a frequently invited speaker at both business and research conferences and has published several articles in academic journals. Furthermore, he is a co-author of the 2010 report "Global Perspectives: Germany" for the Council of Supply Chain Management Professionals (CSCMP). He graduated from the Karlsruhe Institute of Technology in 2009 and received his doctorate in economics from the Technische Universität Berlin in 2013 (summa cum laude). Dr Jan Simon Raue is the corresponding author and can be contacted at: jansimon.raue@gmail.com

Dr Andreas Wieland is an Assistant Professor of Supply Chain Management at the Department of Operations Management, Copenhagen Business School. Andreas' current research interests include supply chain risk management, international logistics strategies, and social responsibility. He is the author of several peer-reviewed journal articles. Andreas is the recipient of several awards, including two Emerald Literati Network Awards for Excellence (2013, 2014), the Harry Boer Highly Commended Award (2012), and an Award for Outstanding Achievements in Teaching at TU Berlin (2014). Andreas teaches classes in logistics and supply chain management. He leads humanitarian logistics courses at various institutions in Ethiopia, Tanzania, and Uganda. Andreas received his doctorate in economics from the Technische Universität Berlin in 2012 (summa cum laude). He is the Editor of the blog scmresearch.org.

This article is (C) Emerald Group Publishing and permission has been granted for this version to appear here 